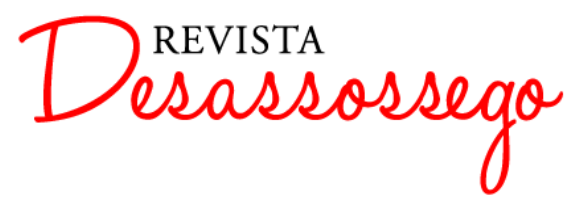

DESASSOSSEGO 17 | JUN/2017 | ISSN 2175-3180

DOI: http://dx.doi.org/10.11606/issn.2175-3180.v9i17p144-163

\title{
O JOGO POÉTICO DE ADÍLIA LOPES: O PASTICHE NA CRIAÇÃO DO SENTIR LÍRICO
}

\author{
Paulo Alberto da Silva Sales ${ }^{1}$
}

Resumo: Partindo dos estudos sobre o pastiche, diferenciando-o da paródia, além das relações tensas entre vida e obra, entre poesia e prosa, entre ficção e realidade, este artigo analisa alguns poemas da poetisa portuguesa contemporânea Adília Lopes presentes nos livros Antologia, publicado em 2002 e em Dobra, publicado em 2009.

Palavras-chave: Pastiche e Paródia. Vida e Obra. Adília Lopes.

\section{The Adília Lopes' poetic play: the pastiche in lyrical feel creation}

\begin{abstract}
From the studies about the pastiche, distinguish it from the notion of parody, beyond the tense relationship between life and work, poetry and prose and fiction and reality, this paper analyses some poems by contemporary portuguese poet Adília Lopes present in the books Antologia, published in 2002 and in Dobra, published in 2009.
\end{abstract}

Keywords: Pastiche and Parody. Life and Work. Adília Lopes.

Fedra está apaixonada/ por Hipólito/ Hipólito não está apaixonado/ por Fedra/ Fedra enforca-se/ Hipólito morre/ num acidente

Dido está apaixonada/ por Eneias/ Eneias não está apaixonado/ por Dido/ Dido oferece uma espada/ a Eneias/ Eneias esquece-se da espada/ quando vai embora/ Dido suicida-se/ com a espada esquecida/ por Eneias

Um desgosto de amor/ atirou-me para um/ curso de dactilografia/ consolo-me/ a escrever automaticamente/ o pior são os tempos livres.

Nas noites de S. João

Marianna Alcoforado

queima alcachofras

Nasci em Portugal

não me chamo Adilia

Sou uma personagem

de ficção científica

escrevo para me casar

Adília Lopes

Os três poemas acima, que servem de epígrafe à reflexão, aqui iniciada, trazem aspectos emblemáticos da dicção lírica da poetisa portuguesa contemporânea Maria José da

\footnotetext{
${ }^{1}$ Doutor em Letras - Estudos Literários - pela Universidade Federal de Goiás. Iniciou, em março de 2017, o primeiro estágio de pós-doutoramento em Literatura Comparada também pela UFG. E-mail: pasticheculture@gmail.com.
} 
Silva Viana Fidalgo de Oliveira ou Adília Lopes. Nascida no ano de 1960, adotaria, em 1983, o pseudônimo Adília Lopes. O eu biográfico, cuja formação literária apresenta uma predileção por autores da tradição e, também, por nomes da cultura moderna e pósmoderna, entrelaça-se com os vários outros sujeitos poéticos criados por Adília Lopes. Em várias entrevistas, essa poetisa afirma possuir vários 'eus' que convivem uns com os outros $^{2}$, de forma que essas várias personalidades se alternam nos seus discursos poéticos. Esta multiplicidade de vozes e de subjetividades mistas criam uma 'nova' realidade poética. Neste trabalho, observaremos como Adília Lopes tece uma poética feita de misturas textuais e discursivas, mediadas pelo pastiche, para expressar um sentir lírico particular, diferenciando-a de vários outros poetas portugueses de fins do século XX e de início do século XXI.

\section{A relação entre vida e obra em Adília Lopes}

No livro Dobra ${ }^{3}$, publicado em 2009 pela editora portuguesa Assírio e Alvim, Adília Lopes reúne quase vinte e cinco anos de criação lírica que tem despertado o interesse da crítica literária pelo aspecto sui generis de seus poemas. Desde a publicação de Um jogo bastante perigoso, em 1985, percebe-se que a poetisa já apresenta as várias questões com as quais ela iria trabalhar ao longo de sua produção poética: a criação de uma subjetividade que permeia entre as experiências de vida em diálogo com as experiências de leitura. Vida e ficção se entrelaçam no discurso poético e esse amálgama desestrutura a noção de literariedade. Além disso, sua 'arte poética' apresenta uma tendência à ficcionalização de aspectos da vida cotidiana que Maria José, a 'poetisa', faz tanto por meio de uma observação astuta dos instantes vividos quanto por uma exímia leitura que a poetisa faz da tradição literária. Sua poética localiza-se aí, neste 'entre-lugar' dos discursos, para utilizarmos a noção do crítico e romancista brasileiro contemporâneo Silviano Santiago.

\footnotetext{
${ }^{2}$ Em uma entrevista cedida a Américo António Lindeza Diogo, publicada em Inimigo rumor (2001), Adília Lopes afirma: "A Adília Lopes e Maria José da Silva Viana Fidalgo são uma e a mesma pessoa. São eu. Como uma papoila é poppy. E muitos outros nomes que eu não sei. A Adília Lopes é água em estado gasoso, a Maria José e a mesma água em estado sólido".

3 Apesar de também citarmos alguns poemas de Antologia, publicada no Brasil, em 2002, pela Cosac \& Naify, comentaremos algumas especificidades e citaremos alguns poemas pertencentes à Dobra. Esse livro reúne todas as publicações de Adília Lopes até o ano de 2009. No título do livro, percebe-se um jogo irônico típico do discurso poético adiliano: Dobra é uma publicação que reúne a edição de a Obra, publicado em 2006, além de outros poemas que a poetisa publicou até o ano de 2009. Aqui, também, não podemos nos esquecer do diálogo explícito que o título estabelece com a noção de dobra discutida por Gilles Deleuze em seu livro $A$ dobra Leibniz e o barroco: uma inflexão, uma mistura e a presença dos vários pontos de vista na mesma matéria: "O ponto de vista sobre uma variação vem substituir o centro de uma figura ou de uma configuração" (DELEUZE, 1991, p. 41).
} 
Retomemos os três poemas citados por nós na epígrafe para exemplificarmos como a poesia de Adília Lopes se constrói a partir da relação tensa entre o ficcional e o vivido. Para expressar a subjetividade a partir de fatos vivenciados pelo eu biográfico, o sujeito poético adiliano retoma autores da tradição (Mariana Alcoforado), temas universais usados como motes em poemas de poetas canônicos (desencontros amorosos), personagens greco-romanas (Hipólito/Fedra/Eneias/Dido) e uma relação íntima de imitação e de readaptação de estilos literários consagrados. Nestas junções, Adília cria um jogo ${ }^{4}$ poético que ressignifica a tradição e cria uma subjetividade lírica marcada pela reunião de elementos diversos que dão sentido à existência do sujeito poético que escreve poesia: "Um desgosto de amor/ atirou-me para um/ curso de dactilografial consolo-me/ a escrever automaticamente/ o pior são os tempos livres".

Em um primeiro momento, o leitor menos acostumado ao modo "excêntrico" do discurso poético adiliano, indaga se o que ele está lendo é, de fato, um poema. Os três poemas anteriores, por associarem estratégias discursivas que se inscrevem no campo do poético e do não poético, causam celeuma e geram inquietudes na representação do sentir lírico de Adília. A associação de traços da vida íntima relacionados aos infortúnios de personagens da tradição - no caso do primeiro poema - permitem uma criação de uma outra 'realidade' que permeia, a nosso ver, em pelo menos três dimensões poéticodiscursivas: i) na dimensão das vivências do eu empírico; ii) nas impressões que esse eu empírico absorveu ao ler os autores canônicos e; iii) na desestruturação e na mescla de identidades que o eu lírico e empírico passam a revezar. Nos poemas já citados, Hipólito e Fedra passam por desilusões amorosas que culminam com a morte de Hipólito. Dido e Eneias também passam por momentos desafortunados cujo fim também é trágico. Motivado pelos infortúnios das personagens da tradição, eu lírico adiliano também sofre por um amor não correspondido que o faz escrever. $O$ ato da escrita marca as subjetividades do sujeito lírico ou, pelo menos, o faz esquecer-se dos pesares, embora o ócio o perturbe.

\footnotetext{
${ }^{4}$ Para entendermos a noção de jogo na poética adiliana, recorremos às reflexões de Jacques Derrida (2008) em sua Gramatologia. A noção de jogo (jeu) seria, segundo esse filósofo, sempre um jogo de 'ausência' e de 'presença' que aparece como a possiblidade de destruição de um significado transcendental. Nos poemas de Adília, veremos, o jogo poético cria um sentir lírico que desestrutura a noção de pacto autobiográfico, no sentido teorizado por Philippe Lejeune (2014). Seus poemas confirmam que, na poesia, há uma vida em jogo, ou melhor, uma nova 'vida' permeada por vários discursos. Negar este aspecto seria, então, anular a própria experiência estética.
} 
No outro poema, Mariana Alcoforado - não aquela freira barroca missivista, mas, sim, um signo manipulado por Adília - queima alcachofras em noites de S. João. O trocadilho feito a partir da sonoridade das letras presentes nos nomes 'Alcoforado' e em 'alcachofras' dá ao poema um tom lúdico, muito embora a aparente simplicidade, a concisão e efemeridade da construção dos versos pouco denotam a complexidade com a qual a poética adiliana é criada. Ao longo das publicações de Maria José, o nome de Sóror Mariana Alcoforado aparecerá em vários poemas e em vários livros. Essas remissões se dão nos poemas de Adília, como também observou Sousa (2014), por meio da leitura das Cartas Portuguesas $^{5}$, nas quais a freira portuguesa expressa suas desilusões amorosas com o seu amado, o marquês Noel Bouton de Chamily, conde de Saint-Léger e oficial francês. Logo, as cartas de Mariana Alcoforado serviram como hipotexto para os poemas de Adília, principalmente àqueles presentes nos livros O marquês de Chamily, publicado em 1987, e em O regresso de Chamily, publicado em 2000.

Já no terceiro poema, o sentir lírico adiliano é verificado através de uma confessionalidade escancarada que coloca em xeque qualquer tipo de hierarquia entre o vivido e o poético, afirmando ser uma personagem de romance que quer se casar. Aqui, o sujeito poético joga com os limites autobiográficos e ironiza a relação entre vida/obra e entre poesia e prosa: Nasci em Portugal/ não me chamo Adília/ Sou uma personagem/ de ficção cientifical escrevo para me casar. Nesse e em vários outros poemas, há mélanges (PROUST, 2009) de elementos díspares que tornam os poemas de Adília peculiares e dignos de uma atenção crítica. Adília Lopes é Maria José e é Dido e é Mariana Alcoforado e é uma personagem de ficção científica e é tudo e é nada. A utilização da conjunção aditiva 'e' aqui é intencional. O sujeito poético adiliano encontra-se descentrado ${ }^{6}$ e desterritorializado ${ }^{7} . \mathrm{Na}$ sua poética,

\footnotetext{
${ }^{5}$ Contemporânea de Pe. Antônio Vieira, a freira barroca Mariana Alcoforado publicou, no século XVII, as Lettres Portugueses, em língua francesa.

${ }^{6}$ Silviano Santiago (1976), em seu Glossário de Derrida, apresenta uma definição precisa sobre a noção de descentramento (décentrement): “A partir de uma leitura desconstrutora do texto artístico, observamos que o significado não possui um lugar mais um lugar fixo (centro), mas, sim, passa a existir enquanto uma construção substitutiva que, na ausência de centro ou origem, faz com que tudo se torne discurso e a produção da significação se estabeleça mediante uma operação de diferenças. Desta forma, eliminando-se qualquer referência a um centro, a um sujeito, e não mais se privilegiando aspecto algum sob o disfarce da 'origem', a atividade interpretativa, com base na polissemia do texto artístico, vai permanecer sempre incompleta, ou noutras palavras, nunca pretendendo chegar a esgotar o significado do objeto-texto na sua totalidade" (SANTIAGO, 1976, p. 16).

7 Aqui, recorremos à noção de desterritorialização apresentada por Gilles Deleuze e Felix Guattari (2010), em Anti-Édipo: capitalismo e esquizofrenia.
} 
[há] um efeito de deslizamento entre vida comum e vida da poesia, tanto na escolha de temas quanto nas opções discursivas. Numa série de jogos de indiscernibilidade entre o discurso comum e o literário, entre poesia e prosa, entre sujeito poético e sujeito empírico, entre intra e o extraliterário, Adília desarticula a fixação de identidades, seja do sujeito ou do texto, manchando a poesia de mundo e propondo-se à árdua e não necessariamente bem sucedida tarefa - devido à própria lógica de inclusão e normalização em que estamos atualmente inseridos - de manchar o mundo de poesia. (EVANGELISTA, 2011, p. 15)

Se o sentir lírico adiliano é criado por meio de jogos discursivos que tencionam os limites entre a vida 'real' e a escrita poética, entre os limites que separam (ou pelo menos separavam) a poesia e a prosa e entre a 'verdade' e a ficção, ficamos ensimesmados quanto à natureza do que seria puramente 'real' e 'poético'. A vida vista como poesia e a poesia vista como vida ou, pelo menos, que cria novas vidas às vivências dos sujeitos, provenientes de vários tempos, espaços e meios. O instante, o tempo cronológico, os acontecimentos diários e o ritmo de vida de Maria José confluem para a presentificação da escrita como ato de existir. Sónia Rita Melo (2016), ao ler os poemas de Adília, também fez uma leitura semelhante à nossa:

\footnotetext{
Nesta instalação artística, a estética do instante enquadra a sua apresentação pública/poética e atribui ao presente, ao momento cronológico, calendarizando, uma função vital possibilitadora da existência da escrita. Em Adília Lopes, a (con)fusão de vida e escrita e a eterna vacilação destes conceitos ondulantes surge, numa primeira abordagem, como imagem de marca desta poetisa. (MELO, 2016, p. 37)
}

À esta estética do instante, é agregada uma dicção autobiográfica forjada. Os dados autobiográficos são desestruturados e passam a conviver com dados literários e, ao mesmo tempo, com dados desimportantes à autobiografia tradicional ou mesmo à noção de pacto autobiográfico criado por Phelippe Leujene (2014). A exposição da vida privada de Maria José é feita por meio de um tom prosaico e, na maioria das vezes, simples, conciso, lúdico, irônico e em forma de trocadilhos. Os biografemas, ou mesmo memórias de Maria José, são manipulados por Adília Lopes - o sujeito poético 'gasoso' - que são preenchidos por outros sujeitos que permeiam o universo adiliano, tal como se evidencia nos poemas a seguir pertencentes às obras A pão e água de colónia, de 1987 e Sete rios entre campos, de 1999, respectivamente:

\section{A AUTOBIOGRAFIA SUMÁRIA DE ADÍLIA LOPES}

Os meus gatos

gostam de brincar 


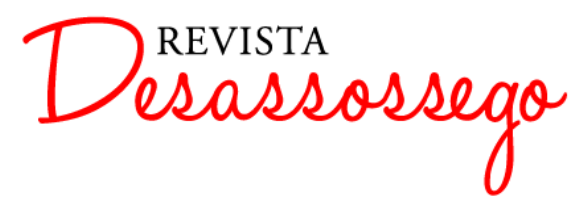

DESASSOSSEGO 17 | JUN/2017 | ISSN 2175-3180

DOI: http://dx.doi.org/10.11606/issn.2175-3180.v9i17p144-163

com as minhas baratas

(LOPES, 2009, p. 72)

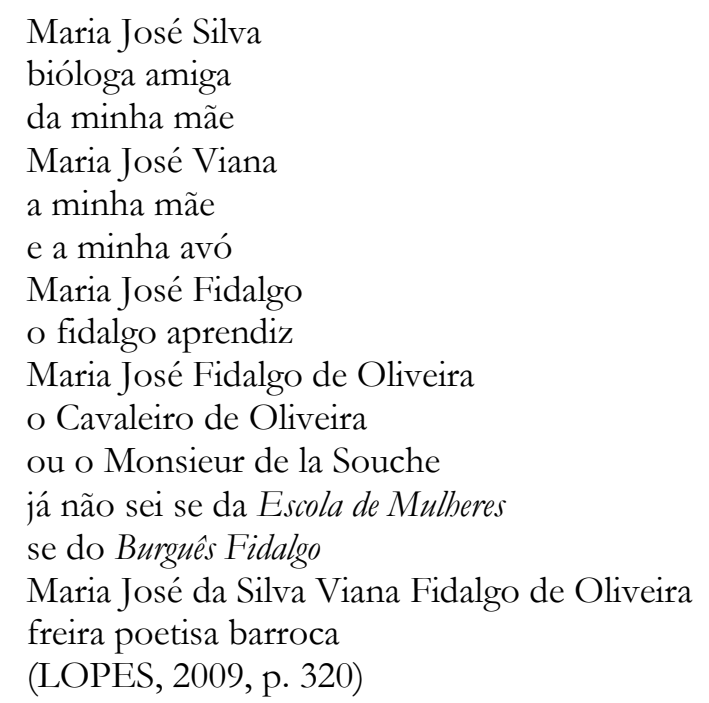

As várias feições que o eu lírico assume nos versos mostram a transitoriedade tanto das memórias vivenciadas quanto das lidas e incorporadas por Adília. A relação autor/eulírico nos poemas sabota a noção de pacto autobiográfico, mais especificamente, da relação de correspondência fidedigna no pronome 'eu' (entre o autor e o eu lírico). Os espaços biográficos, cujas referências partem do universo pessoal de Adília, são preenchidos por remissões textuais, flashes de fatos corriqueiros vividos e por outras vivências de sujeitos pertencentes ao universo doméstico de Maria José. A imagem de uma mulher de classe média, cinquentona, amante de gatos, católica e, sobretudo, ligada ao ambiente familiar marcam o caráter confessional de sua poesia. Outrossim, lembremo-nos que essa aparente 'verdade' corrobora com o desmoronamento dos limites do que seria verdade e ficção. Outro poema intrigante que também apresenta um desnudamento autoral seria o "Body art?":

\section{BODY ART?}

Com os remédios engordo $30 \mathrm{~kg}$ o carteiro pergunta-me para quando

é o menino nos transportes públicos as pessoas levantam-se para me dar o lugar sento-me sempre 


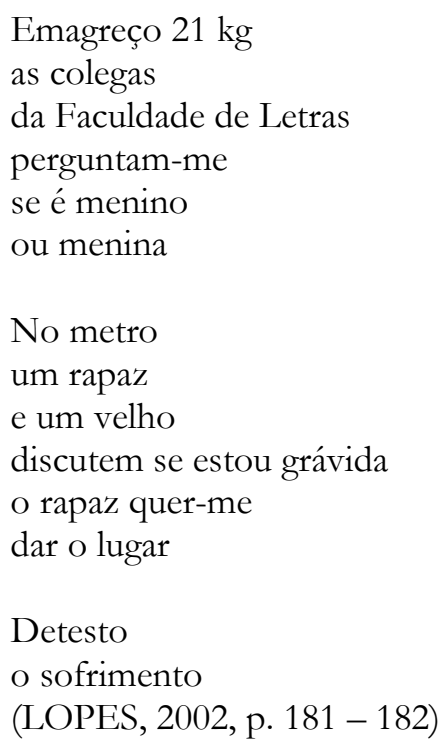

Aqui, o sujeito poético se autoironiza desde o título. As descrições cômicas de si e da forma como o sujeito poético é interpretado pelos outros ao seu redor confirmam uma tônica da pós-modernidade: o corpo como objeto de desejo, de consumo e de poder. $\mathrm{O}$ sujeito poético é avaliado por pessoas banais que emitem julgamentos baseados no sobrepeso de Adília Lopes e, consequentemente, na sua perda de peso. Essas descrições de cunho autoral evidenciam os pré-conceitos existentes na contemporaneidade e que, provavelmente, o sujeito empírico Adília Lopes vivenciou e/ou ainda vivencia. A banalidade, a trivialidade e o desimportante tomam conta da poesia de Adília em que, assim como em Mallarmé e Baudelaire, o esterco lírico e as eventualidades passam a ser consideradas como matérias poéticas e têm sua importância no fazer poético.

Por meio de uma dicção narrativa que em muitos momentos se aproxima de uma dicção de um contador de histórias da carochinha, Adília, em vários livros, cria uma espécie de narrador que se ocupa, por ora, dos poemas e tece alguns comentários de caráter metafictício ao se indagar sobre como são narradas as histórias, quem eram as personagens e o que elas faziam. O poema a seguir comprova essa questão:

Ou a história não era bem assim?

a história não era bem assim

Nesse romance era um russo emigrado que fazia cavalinhos nas costas da cama de mogno da rapariga parisiense que reduzira enquanto juntos traduziam uma fábula de Krylow 
(LOPES, 2002, p. 134)

Ainda seguindo o tom ficcional, o eu lírico adiliano em vários momentos traz para o campo da lírica estratégias da narrativa ficcional, principalmente o tom narrativo com um teor autorreflexivo. Vários poemas possuem um caráter especular ao indagarem sobre a natureza da escrita poética, fato este que os tornam metafictícios. O seguinte poema presente no livro Dobra ilustra essa problemática:

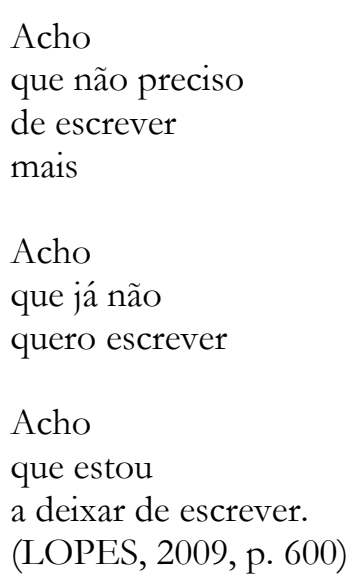

Seja pela dicção ficcional ou pela dicção que permeia experiências do vivido e do lido, o sujeito poético na poesia de Adília Lopes é criado por discursos lúdicos e irônicos que nos revela um sentir lírico semelhante ao de alguns poetas brasileiros dos anos 1970 do século XX, principalmente os concretistas Augusto e Haroldo de Campos, ou mesmo de grande parte da poética de Francisco Alvim. Mas essas fricções de discursos e de jogos de linguagem na tessitura dos poemas de Adília são construídas por meio de remissões, referências, intertextos, paratextos e hipotextos que são reorganizados por meio da uma prática hipertextual conhecida como pastiche. Vejamos como essa prática intertextual se materializa na poética adiliana.

\section{O pastiche no discurso lírico adiliano}

Vimos que a poética adiliana utiliza discursos diversos para a construção de um jogo poético difuso. Sua criação parece ser simplista ou mesmo primária. Contudo, nesta proposta de desconstrução de identidades fixas, Adília Lopes recorre a elementos intertextuais, sobretudo, ao pastiche, como estratégia formal para homenagear, dialogar e reler autores e adotar estilos da tradição e da modernidade literária. 
Adília, ao tratar das experiências de leituras feitas a partir de um tom dialógico, acaba fazendo pastiches. Sua poesia, por meio do pastiche, está desenraizada de sentidos, muito embora sua poética não desarticule experiências de vida e assuntos que enlaçam o leitor. O que se verifica é uma substituição dos modos próprios do sentir lírico por uma subjetividade forjada ${ }^{8}$. Goiandira Camargo (2008, p. 100), remetendo ao artigo "Poesia e memória”, de Paulo Henriques Brito, entende que esse tipo de poesia foi denominada póslírica, ou seja, seria aquela poesia remanescente do concretismo e que mais sofreu influência desta prática. Resultou, então, em uma poesia na qual a "episteme reservada ao lírico se apaga, dando lugar a referências, remissões, citações de escrituras literárias" (CAMARGO, 2008, p. 100). O poema a seguir, pertencente ao livro Sete rios entre campos, confirma os dizeres de Camargo:

\section{EMILY DICKINSON}

Mesmo que pudesse

dizer tudo

não podia dizer tudo

e é bom assim

\section{S. JOÃO DA CRUZ}
Mesmo que pudesse
dizer tudo
não podia dizer tudo
e é bom assim

(Aprendei a AMAR

os boletins meteorológicos

e $A$ tempestade

e as tempestades)

"Les jours s'en vont je demeure"

(GUILLAUME APOLLINAIRE)

"Le pont Mirabeau"

Os DIAS VÃO-SE

Eu não

(LOPES, 2002, p. 185)

\footnotetext{
${ }^{8}$ Algumas indagações presentes neste e em outros parágrafos estão presentes, também, de forma inicial, em um estudo que publicamos em 2012 na revista Refacer, intitulado "Releitura das linhas de força moderna e modernista na poesia lírica pós-moderna de Adília Lopes". Ao fazermos uma autocitação, modificamos o teor de algumas reflexões e adequamos à vertente do artigo que agora escrevemos, cujo foco é trabalhar o aspecto imitativo do pastiche e do jogo na poética de Adília Lopes.
} 
Neste poema, o eu lírico cede espaço às citações de poetas e autores da tradição, às referências literárias canônicas, além de apresentar trocadilhos, jogos de palavras e uma proposta de desconstrução de biografias, que são entrecortadas por ideias semelhantes às do sujeito poético. Essa prática de apagamento do lírico para ceder lugar às citações, signos, símbolos, nomes e estilos da poética erudita em Adília Lopes é feita, segundo Rosa Maria Martelo (2004), através da remissão de nomes importantes da poesia e da prosa moderna (Rimbaud, Apollinaire, Cesário, Pessoa, Herberto Helder) e de outros autores da literatura ocidental (Diderot, Mariana Alcoforado, S. João da Cruz, Virgílio). Nesta releitura, Adília cria novas construções em forma de colagens, de reorganizações textuais e com enxertias que fazem transparecer um sentir lírico que os tornam diferentes dos originais. Fernando Pessoa, na figura do heterônimo Ricardo Reis, aparece em vários poemas adilianos em uma dicção que nos remete diretamente à lírica pessoana. Vejamos um poema presente no livro Os 5 livros de versos salvaram o tio, pertencentes à Dobra:

\section{Pega tu nelas RICARDO REIS}
Mão morta vai bater àquela parte as rosas amo do jardim de Adónis ao escrever é preciso reconciliar uma lebre com uma tartaruga oh como era lebre a tartaruga

Mas porque será sempre Lídia a pegar nas rosas Dr. Ricardo Reis? (LOPES, 2009, p. 163)

O leitor nota uma semelhança tanto na construção dos versos quanto nas remissões aos temas ligados à poesia clássica de Ricardo Reis. Mas a leve semelhança proporcionada pelo pastiche logo é aprofundada quando o eu lírico insere novas roupagens e aspectos ao tom e ao estilo do poeta que foi retomado. Nos versos Mas porque será sempre Lídial a pegar nas rosas/ Dr. Ricardo Reis?/ o eu lírico constrói um questionamento à própria construção e à prática de ser diferente ao seu tempo e de "assistir ao espetáculo do mundo" criada por Ricardo Reis. Por isso, nesse e em vários outros poemas adilianos, o pastiche cria uma relação imitativa ao homenagear uma fonte ou um hipotexto, mas sua construção torna-se diferente ao passo que ela é constextualizada com o sentir lírico do agora: Mão morte vai bater 
àquela parte/ as rosas amo do jardim de Adónis/ ao escrever/ é preciso reconciliar uma lebre/ com uma tartarugal ob como era lebre a tartaruga.

O diferencial na reorganização dos tantos fragmentos provenientes de fontes díspares está na inserção decisiva da ironia, já presente na modernidade e intensificada na pós-modernidade pelo pastiche. Por essa razão, percebe-se que a ironia utilizada por Lopes na confecção do poema é diferente daquela ironia presente na paródia modernista ${ }^{9}$. Ela não parodia o termo "musa" por meio de artifícios jocosos, sarcásticos ou antitéticos para questionar ou anular o seu sentido maior. Muito pelo contrário. Há um resgate efervescente da função da musa no fazer poético que, por sua vez, chama a atenção da poetisa pósmoderna para não propagar cantos a esmo. Lopes constrói, por sua vez, pastiches, ou seja, homenagens reflexivas moldadas por jogos de linguagem extremamente irônicos. Mas quais seriam os aspectos teóricos que sustentam os usos do pastiche e porque ele é uma estratégia poética comum em Adília? Vejamos, paulatinamente, essas questões.

O pastiche, assim como a paródia, são, segundo Gérard Genette (1982), imitações de estilos. Ambos trabalham com as recodificações dos códigos nos jogos textuais. O diferencial é que, no pastiche, há uma mistura, uma mescla, uma costura e uma bricolagem de códigos cuja função primeira é criar a semelhança pela repetição. No caso específico da paródia contemporânea, o hipertexto ressalta a diferença na repetição. O pastiche comporta uma mistura heterogênea e traz consigo a semelhança de um estilo que se reproduz em uma escritura monotextual. A paródia, por sua vez, ao transcontextualizar os códigos ironicamente, transforma-os.

A noção de pastiche, desde sua acepção etimológica, deriva da palavra italiana pasticcio e significa "massa opaca ou amálgama de elementos compostos". Para Ingeborg Hoesterey (2001), o pastiche compartilha do princípio da adaptação, da apropriação, da bricolagem, da colagem, da imitação fraudulenta, da montagem, do palimpsesto, do plagiarismo, da reciclagem, da refiguração, do simulacro e do travestimento. Margaret Rose

${ }^{9}$ Diferentemente do pastiche e da paródia modernista, a paródia pós-moderna, teorizada por Linda Hutcheon (1985), em Uma teoria da paródia, apresenta uma autorreflexividade intensa típica do pós-modernismo. Isso fez com que a paródia não fosse utilizada, apenas, como um hipertexto que ataca de forma crítica e jocosa o hipotexto, mas, sim, enquanto uma "repetição com distância crítica" (HUTCHEON, 1985, p. 17) que marca a diferença em vez da semelhança. Sob esta perspectiva, a crítica não deve estar presente, necessariamente, no riso, no escárnio ou na sátira moralizante. Aliás, esta proposta envolve os primeiros usos da paródia nas manifestações carnavalescas, burlescas e cômicas da tradição. Mas ela não está isenta destes aspectos na contemporaneidade: o que refletimos aqui é que a paródia é mais que isso. A paródia torna-se "uma confrontação estilística" e "uma recodificação moderna que estabelece a diferença no coração da semelhança" (HUTCHEON, 1985, p. 19). Veremos, adiante, que o pastiche se assemelha, em partes, à paródia pósmoderna, mas ele acentua a semelhança na repetição, e não a diferença. 
(1993) apresenta uma definição prévia importante para entendermos o pastiche como um hipertexto pós-moderno:

[o pastiche] não apenas descreve uma combinação de elementos a partir de outras obras cuja intenção não era apenas retomar estilos, mas a recombinação de diferentes elementos propostos pelo pastiche é entendida como criações originais e que podem receber vários significados. (ROSE, 1993, p. 27) (tradução nossa)

Rose entende que o pastiche seria uma recombinação de vários elementos textuais oriundos de diferentes obras que, uma vez reorganizados, passam pelo processo de ressignificação e adquirem, assim, novos sentidos. Nas suas primeiras manifestações, o pastiche foi aplicado de forma pejorativa no campo das artes plásticas, uma vez que forjava com tal perícia imitativa ser confundido com o original. Já na Renascença, o termo foi muito utilizado para designar "pintores medíocres" que imitavam quadros de grandes mestres italianos com intenções fraudulentas.

É necessário ressaltarmos que a prática imitativa é bastante anterior à criação do termo. Na literatura, especificamente, o pastiche acontece por meio da reunião de estilemas e códigos de textos pré-existentes que são costurados e recebem novas molduras. Imitação afetada do estilo de um ou mais autores, o pastiche, forma claramente derivativa, põe a tônica na manipulação de linguagens, contrapondo diversos registros e níveis de língua com finalidade estética e lúdica.

Deliberadamente cultivado tanto no passado quanto na pós-modernidade, o pastiche afirma-se como a escrita "à maneira de", além de fazer usos adaptativos, tais como a modificação de material artístico de gênero para gênero e de uma forma para outra distinta, a apropriação ou empréstimo estilístico, a bricolagem, a confecção artística a partir de fontes e modelos heterogêneos, além da montagem de fragmentos oriundos de fontes díspares.

Genette (1982) entende, também, que o pastiche é, em termos aristotélicos, mais potente do que o metatexto (comentários sobre o hipotexto). Sendo mais livre nos seus modos, o hipertexto ultrapassa sem reciprocidade. A imitação proposta pelo pastiche pode ser lida por si mesma e comporta uma significação autônoma.

O pastiche na pós-modernidade, segundo Hoesterey (2001), trata da imitação de um estilo que resgata a memória cultural do passado e do presente de forma crítica. Há nas suas costuras o confronto de gêneros mediados tanto da alta cultura quanto da cultura de massa, simultaneamente e entrelaçadamente. 
Também sob a perspectiva da repetição deleuziana, embora ressaltando a semelhança e não a diferença, o pastiche, segundo Hutcheon (1985, p. 55), geralmente permanece dentro do mesmo gênero que o seu modelo, ao passo que a paródia permite adaptação. Rememorar e repetir em forma de pastiche é acentuar a semelhança no hipertexto. Essa visibilidade da retomada imitativa foi trabalhada também por Proust (2009) nas suas misturas e releituras dos textos de Flaubert.

Este aspecto, a intenção, é primordial na diferenciação entre o pastiche e o plágio. A decodificação feita pelo leitor ao adentrar no jogo da reescrita em pastiche logo destaca a semelhança e uma homenagem. Por apresentar "uma prática neutra" (ROSE, 1993), o pastiche não necessita obrigatoriamente de veia crítica e nem da comicidade nas suas abordagens.

Esta constatação que Rose (1993) realiza aproxima-se bastante da concepção de pastiche segundo a visão de Jameson (1985, p. 18-19):

O pastiche é como a paródia, a imitação de um estilo singular ou exclusivo, a utilização de uma máscara estilística, uma fala em língua morta: mas a sua prática desse mimetismo é neutra, sem o impulso satírico, sem a graça, sem aquele sentimento ainda latente de que existe uma norma em comparação com a qual aquele que está sendo imitado é, sobretudo, cômico. O pastiche é a paródia lacunar, paródia que perdeu seu senso de humor.

Jameson $(1985 ; 1997 ; 2006)$ associa dois termos que configuram o "mal-estar" no pós- modernismo: o pastiche e a esquizofrenia. O que acontece, então, com o pastiche, na visão do crítico norte-americano, é que não mais interessa fazer releitura do passado e apontar as possíveis verdades postas à prova através da ironia, como faziam as paródias no alto modernismo. Importa agora, segundo Jameson, resgatar os mestres singulares, trazer à tona seus estilos e discursos em uma atualidade diferente daquela em que foram feitos.

No caso da poética adiliana, o pastiche é a estratégia intertextual mais frequente ${ }^{10}$, haja vista que sua poética é mediada por várias fontes intertextuais que são bricoladas e reorganizadas nos jogos poéticos. Além disso, não se percebe, pelo menos nos poemas que nos servimos para essa reflexão, uma releitura crítica que acentua a diferença no coração da semelhança, aspecto esse fundamental para entender a noção de paródia pós-moderna estudada por Hutcheon (1985). Não obstante, o hibridismo, o tom de enxertia, as colagens, as retomadas de frases soltas agrupadas aos poemas ressaltam os principais elementos de

10 Isso não impede que vários outros poemas sejam feitos por meio da paródia pós-moderna ou mesmo pela paródia tradicional com viés crítico e satírico. 
pastiche na poesia. Essas misturas e cruzamentos de elementos textuais oriundos de meios distintos cria um sentir lírico diferenciado, pautado naquilo que Deleuze e Guattari (2010) entendem como "totalidades ao lado". Para estes pensadores pós-estruturalistas,

estamos na idade dos objetos parciais, dos tijolos e dos restos. Já não acreditamos nesses falsos fragmentos que, como pedaços de uma estátua antiga, esperam ser contemplados e reagrupados para comporem uma unidade que é, também, a unidade de origem. Já não acreditamos na grisalha de uma insípida dialética evolutiva, que pretende pacificar os pedaços arredondando suas arestas. (DELEUZE; GUATTARI, 2010, p. 62)

As especulações de Deleuze e Guattari (2010) em relação ao problema da descodificação e da desterritorialização dos fluxos, juntamente às propostas de enxertia do pastiche pós-moderno de produzir uma arte deslegitimadora são encontradas na produção lírica de Adília Lopes. Ela trabalha poeticamente com poemas em formatos de jogos textuais, suplementos, reelaborações e questionamentos dos gestos da história no seu interesse profundo pela tradição literária. No entanto, essa retomada "ao lado" da tradição aparece nos poemas de Adília Lopes em textos mediados e feitos como "totalidades ao lado". Nos poemas, essas totalidades são o todo dessas partes, sem o intuito de unir um sentido unívoco. Por isso, é tão comum aparecer citações de trechos de obras de autores e mesmo de elementos corriqueiros vividos pela poetisa. As influências da tradição permeiam os discursos do sujeito poético e seus poemas passam a apresentar identidades plurais. As referências e citações não são idênticas aos originais. Cria-se a originalidade no jogo poético das escritas do presente da poetisa. O poema a seguir exemplifica nossa reflexão:

\title{
FLORBELA ESPANCA ESPANCA
}

\author{
Não gosto tanto \\ de livros \\ como Mallarmé \\ parece que gostava \\ eu não sou um livro \\ e quando me dizem \\ gosto muito dos seus livros \\ gostava de poder dizer \\ como o poeta Cesariny \\ olha \\ eu gostava \\ é que tu gostasse de mim \\ os livros são feitos \\ de carne e osso \\ e quando tenho \\ vontade de chorar
}




\author{
abrir um livro \\ não me chega \\ preciso de um abraço \\ mas graças a Deus \\ o mundo não é um livro \\ e o acaso não existe \\ no entanto gosto muito \\ de livros \\ e acredito na Ressureição \\ dos livros \\ e acredito que no Céu \\ haja bibliotecas \\ e se possa ler e escrever \\ (LOPES, 2002, p. 189-190)
}

Influenciado por Mallarmé e Cesariny, o sujeito poético questiona sua relação com os livros e como esses mesmos livros the possibilitam criar subjetividade: livros, assim como o sujeito poético adiliano, são de carne e osso. O mundo não é um livro, entretanto, eles são essenciais à constituição do sentir lírico da poetisa e ela espera encontrá-los no céu. Ou seja, a constituição do eu adiliano é fluido e múltiplo e depende de outros elementos para a sua constituição.

Em "O luna-parque", poema inserido no livro Um jogo bastante perigoso, Adília também trabalha com o 'afastamento figural' ao usar uma objetividade baseada em narrativas comezinhas e, ao mesmo tempo, nesse simulacro pós-moderno, a poetisa insere o tom prosaico e imagético ao mesclar signos dessemiotizados criando uma nova ilusão referencial que não é o real: Eu julgava que aquilo era / um Luna Parque / saía-se como se entrava I e não acontecia nada irreversivel durante [...] quando dei por mim / já estava lá dentro / e não me lembrava / de ter entrado [...]. Do "luna-parque não se sai": há um imenso caleidoscópio no qual o sujeito poético terá que se acostumar junto as simulações do mundo pós-moderno. A hipotética conclusão do eu-lírico é que no Luna Parque que é / um sítio triste / pode não ser triste / sai muito caro / mas poder pode-se. (LOPES, 2002, p. 9-10)

Outro poema de semelhante problemática é "Um quadro de Rubens". Nele, Lopes também usa a ironia para compor a ilusão referencial e, ao mesmo tempo, se fixa no processo de figuração prosaica. Eis o poema na íntegra:

\title{
UM QUADRO DE RUBENS
}

\author{
Vi-me comprimida \\ num ajuntagente \\ ora eu só suporto pessoas à distância \\ de preferência com uma mesa de permeio \\ acontece que uma mulher que foi projectada
}




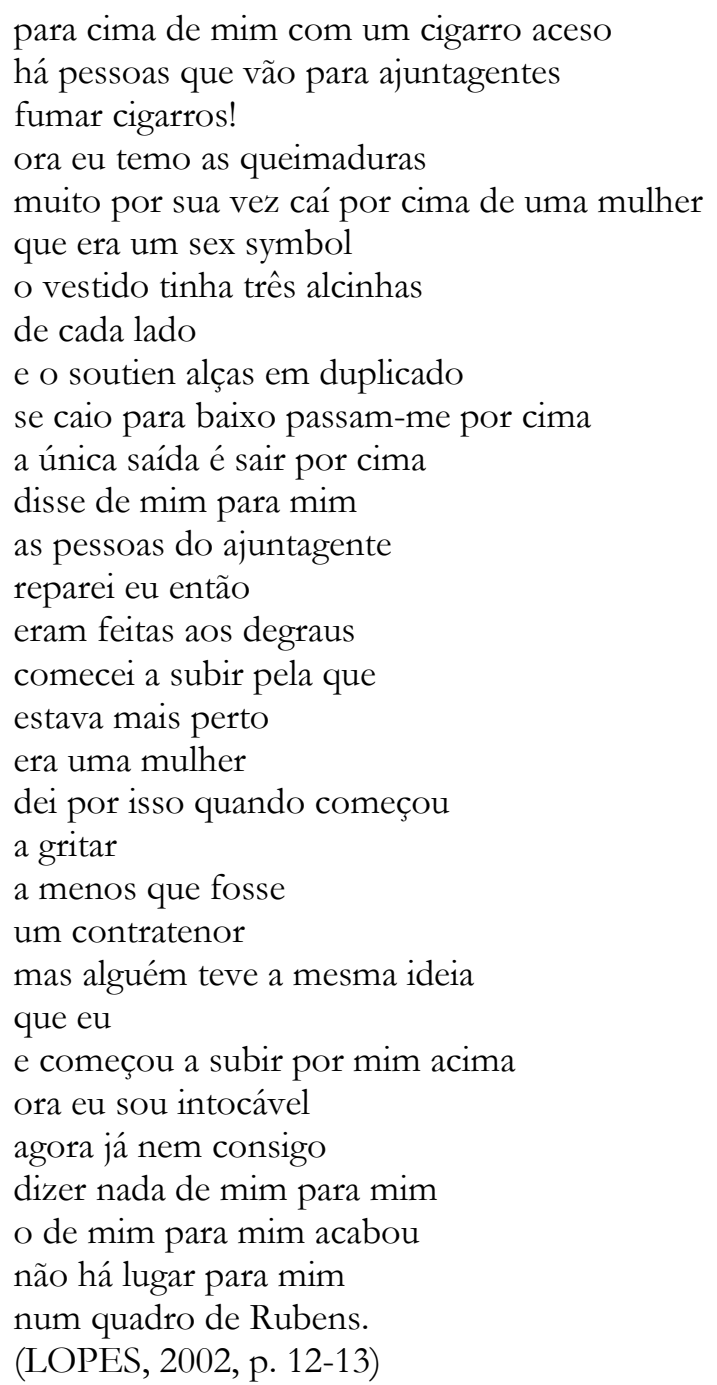

É inegável não sentir a presença emaranhada de elementos díspares na composição do poema. O sujeito lírico se acopla numa imensa rede de imagens desconexas que são unidas às expressões negativistas do sentir lírico do poeta. A insatisfação e o descontentamento frente ao não-lugar do poeta na pós-modernidade podem ser apreendidos como argumento maior do poema. O fato de "alguém ter a mesma ideia que eu" e de o sujeito lírico nem conseguir expressar-se, por si só, já que "o de mim para mim acabou", revela uma ironia sagaz de Lopes ao adotar uma postura pautada na impropriedade que, a nosso ver, seria uma diferença substancial no oposição paródia versus pastiche. Célia Pedrosa (2007), apoiando-se nas semelhanças irônicas de Charles Baudelaire e Adília Lopes, ambos poetas de fins de século, reconhece, também, a presença das marcas da impropriedade irônica de si mesmo e do outro, simultaneamente no jogo imagético e 
híbrido do pastiche. O último resultado seria o apagamento das identidades por meio das dicotomias, hierarquias e, parafraseando Derrida (2008), por meio da "diferencias".

Restou, então, ao poeta pós-moderno, como único meio de sobressair ao turbilhão de cacoetes e restos de objetos dessegmentados, montar poemas especulativos em forma de puzzles $^{11}$. A esquizofrenia temporal destacada por Jameson (1997) embaralha os tempos e os agentes da história. O poeta, no seu "último" ato de lirismo, expressa seu sentir nas reformulações das ficcionalizações da literatura, da história e do cotidiano, tal como constatamos nas homenagens que Adília faz ao romancista e filósofo Denis Diderot:

\begin{abstract}
AO POETA DE PONDICHÉRY (1986)
Diderot (ou quem fala por ele em Jacques le Fataliste) recebe um jovem que escreve versos. Acha os versos maus e diz ao jovem que ele há-de fazer sempre maus versos. Diderot preocupa-se com a fortuna do mau poeta. Pergunta-lhe se tem pais e o que fazem. Os pais são joalheiros. Os pais são joalheiros. Aconselha-o a partir para Pondichéry e a enriquecer lá. E a que sobretudo não publique versos. Doze anos mais tarde o poeta volta a encontrar-se com Diderot. Enriqueceu em Pondichéry (juntou 100000 francos) e continua a escrever versos.
\end{abstract}

Porque é que o mau poeta deve ir para Pondichéry e não para outro lugar? Porque é que os seus pais são joalheiros? Porque é que juntou 100 000 francos? E porque é que passou doze anos em Pondichéry? Não sei explicar. O que me atrai é precisamente isto: Pondichéry, pais joalheiros, 100 000, doze anos.

10.11.1986.

(LOPES, 2002, p. 31)

Publicado em 1986, o livro de poemas intitulado O poeta de Pondichéry resgata uma figura canônica e amada pela poetisa portuguesa. Diderot, a figura autoral, agora passa a ser signo nas moldagens pastichiadas de Adília que faz, por sua vez, "autoficcionalizações autorais" (SÜSSEKIND, 2002, p. 207). Os campos referenciais escolhidos por Lopes presentes no poema representam, tal como entende Deleuze e Guattari (2010), várias reescrituras de estórias e os eternos retornos aos livros num gesto de reapropriação: Tenho as gavetas cheias de papéis escritos / poemas e cartas que não cheguei a mandar a Diderot / os poemas escrevi-os num papel branco / não sou capaz de escrever um poema num leque / depois do que Diderot me disse / se quer ouvir dizer que os seus poema são bons / procure outra pessoa (LOPES, 2002, p. 45). E em [...] nos montes não há pedras boas ou pedras más / e nos livros há poemas bons e poemas maus / [...] os papéis que os herdeiros vão encontrar / depois de sua morte / parecem palimpsestos / mas as emendas

11 Aqui, também, retomamos a reflexões que já desenvolvemos incialmente em nosso artigo já citado anteriormente e publicado em 2012. 


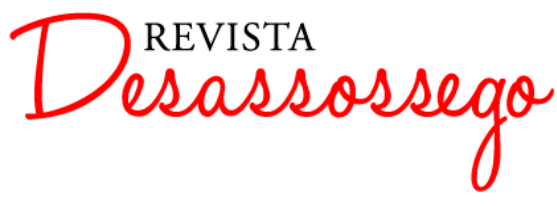

DESASSOSSEGO 17 | JUN/2017 | ISSN 2175-3180

DOI: http://dx.doi.org/10.11606/issn.2175-3180.v9i17p144-163

são como eczema / sobre uma pele que nunca se esgotou (LOPES, 2002, p. 34). Esses gestos de transposição de identidade ficcional para outro universo poético-narrativo apresentam a peculiaridade de serem enxertados às perspectivas enunciativas do eu-lírico adiliano: Não sei explicar. O que me atrai é precisamente isto: Pondichéry, pais, joalbeiros, 100000 francos, doze anos. (LOPES, 2002, p. 31)

As transferências de personalidades são alternativas ao sujeito lírico, num gesto palimpséstico de revisar e reescrever sobre as reemendas dos pergaminhos, formam eczemas "sobre a pele que nunca se esgotou". Nessas tentativas herméticas de criação do poético, Adília abre espaço para a demarcação de suas subjetividades presentes nos elogios, homenagens, censuras, advertências e até mesmo nas depreciações sobre a atual condição do poeta. Tais fatos encontram explicação nos dizeres de Derrida (2005), uma vez que o “comuto (logos) dos suplementos (ao pai-capital-bem-origem etc.), com o que vem além do um no movimento próprio que ele se ausente e se torna invisível, solicita, assim, ser suprimido, com a diferença e a diacriticidade.” (DERRIDA, 2005. p. 28)

Por fim, constatamos que Adília Lopes, em uma via oposta à de outros grandes nomes da poesia portuguesa contemporânea, cria uma poética mista que permeia entre as experiências do vivido e as experiências e reminiscências textuais da tradição para exprimir o sentir lírico em discursos poéticos multifacetados moldados pelo pastiche. Seus poemas criam novas "realidades", que não têm compromisso com a verossimilhança aristotélica, mas sim com a envergadura textual e com a própria realidade discursiva. Em Adília, há a repetição, não da cópia, mas, por meio do pastiche, do suplemento da escritura.

\section{Referências}

CAMARGO, Goiandira. Subjetividade e experiência de leitura na poesia lírica brasileira contemporânea. In: PEDROSA, Célia; ALVES, Ida. Subjetividades em devir: estudos de poesia moderna e contemporânea. Rio de Janeiro: 7 Letras, 2008, p. 99 - 107.

DELEUZE, Gilles. Leibniz, e o barroco. Tradução Luiz B. L. Orlandi. São Paulo: Papirus, 1991.

DELEUZE, Gilles; GUATTARI, Félix. O anti-édipo: capitalismo e esquizofrenia. Tradução Luiz B. L. Orlandi. São Paulo: Editora 34, 2010. 


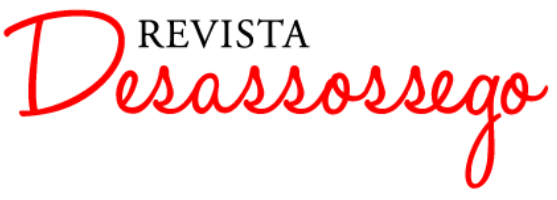

DESASSOSSEGO 17 | JUN/2017 | ISSN 2175-3180

DOI: http://dx.doi.org/10.11606/issn.2175-3180.v9i17p144-163

DERRIDA, Jacques. A farmácia de Platão. Tradução Rogério Costa. São Paulo: Iluminuras, 2005.

Gramatologia. Tradução Miriam Chnaidermam e Renato Janine Ribeiro. São Paulo: Perspectiva, 2008.

DIOGO, Américo. Entrevista com Adília Lopes. In.: Inimigo Rumor. N. 10. Rio de Janeiro: 7 Letras, 2001.

EVANGELISTA, Lúcia. A vida em comum: a poética de Adília Lopes. Dissertação de Mestrado em Estudos Literários, Culturais e Interartes. Faculdade de Letras da Universidade do Porto, 2011.

GENETTE, Gérard. Palimpsestes: la littérature au second degré. Paris: Éditions du Seuil, 1982.

HOESTEREY, Ingeborg. Pastiche: cultural memory in art, film and literature. New York: Indiana University Press, 2001.

HUTCHEON, Linda. Uma teoria da paródia: ensinamentos das formas de arte do século XX. Tradução Teresa Louro Pérez. Lisboa: Edições 70, 1985.

JAMESON, Fredric. Pós-modernidade e sociedade de consumo. Novos Estudos/CEBRAP. jun./1985, n.12. p. $16-26$.

- Pós-modernismo: a lógica cultural do capitalismo tardio. Tradução Maria Eliza Cevasco. São Paulo: Ática, 1997.

A virada cultural: reflexões sobre o pós-modernismo. Tradução Carolina Araújo. Rio de Janeiro: Civilização Brasileira, 2006.

LEJEUNE, Philippe. O pacto autobiográfico: de Rousseau à internet. Tradução Jovita Maria Gerheim Noronha e Maria Inês Coimbra Guedes. Belo Horizonte: Editora UFMG, 2014.

LOPES, Adília. Antologia. São Paulo/Rio de Janeiro: Cosac \& Naify/7 Letras: 2002.

Dobra: poesia reunida. Lisboa: Assírio \& Alvim, 2009.

MARTELO, Rosa. Adília Lopes - ironista. Scripta, Belo Horizonte, v. 8, n. 15, p. 106 - 116, 2004.

MELO, Sónia. As sete vidas de Adília Lopes ou o renascer da "mulher-osga". Convergência Lusiada. n. 35, Jan. - Jun., 2016.

PEDROSA, Célia. Poesia contemporânea: crise, mediania e transitividade (uma poética do comum). In: PEDROSA, Célia; ALVES, Ida. Subjetividades em devir: estudos de poesia moderna e contemporânea. Rio de Janeiro: 7 Letras, 2008, p. 41 - 50. 
Adília e Baudelaire: leituras do fim. Alea: Estudos Neolatinos, Rio de Janeiro, v. 9, n. 1, p. $118-130,2007$.

PROUST, Marcel. Pastiches et mélanges. Paris: Éditions L’imaginaire Gallimard, 2009.

ROSE, Margaret. Parody: ancient, modern and post-modern. New York: Cambridge University Press, 1993.

SALES, Paulo. Releitura das linhas de força moderna e modernista na poesia lírica pósmoderna de Adília Lopes. Revista Refacer. p. 1 - 17, 2012.

SANTIAGO, Silviano. Glossário de Derrida. Rio de Janeiro: Francisco Alves Editora, 1976.

SOUSA, Phabulo. A tessitura poética de Adilia Lopes. Dissertação de Mestrado em Letras Clássicas e Vernáculas da Universidade de São Paulo. 2014.

SÜSSEKIND, Flora. Com outra letra que não a minha. In: LOPES, Adília. Antologia. São Paulo: Cosac \& Naify, 2002. 